\title{
Childhood Primary Cutaneous Anaplastic Large Cell Lymphoma
}

National Cancer Institute

\section{Source}

National Cancer Institute. Childhood Primary Cutaneous Anaplastic Large Cell Lymphoma. NCl Thesaurus. Code C7211.

An anaplastic large cell lymphoma that occurs during childhood and is limited to the skin at the time of diagnosis. 